\title{
PERAN LEMBAGA PERKREDITAN DESA (LPD) DALAM MEMBERIKAN PELAYANAN PADA MASYARAKAT DESA LEGIAN
}

\author{
Made Eka Agustini \\ Universitas Pendidikan Nasional \\ ekaagustini245@gmail.com
}

\begin{abstract}
ABSTRAK
Pulau Bali selain memiliki kelurahan dan desa yang bersifat adiministratif juga memiliki desa yang mempunyai sifat otonomi asli dengan sebutan Desa Adat atau Desa Pakraman. Pemerintah Provinsi Bali dalam hal ini memiliki salah satu lembaga keuangan milik masyarakat tingkat desa yaitu LPD. Berdiri dan berkembangnya LPD di Bali pada dasarnya untuk membantu pembangunan di tiap-tiap Desa Adat sebagai kekuatan untuk menjaga adatnya. Peran penting LPD sangat dirasakan oleh masyarakat terutama untuk mendukung kegiatan seperti odalan dan hari raya besar umat hindu. Penelitian ini dilakukan dengan tujuan untuk mengetahui bagaimanakah eksistensi lembaga perkreditan desa dalam memberikan pelayanan pada masyarakat desa adat legian. Metode penelitian yang digunakan dalam penelitian ini deskriptif kualitatif. Teknik pengumpulan data yang digunakan adalah observasi, dokumentasi, wawancara. Teknik analisis data yang digunakan adalah penyajian data, analisis data, kesimpulan. Kepala Pimpinan selama menjabat sudah melaksanakan proses pelayanan yang baik. Selain itu Kepala Pimpinan LPD dalam menjalankan tugasnya memiliki aturan berdasarkan SOP. Jenis pelayanan yang ada di LPD legian sudah diterapkan lebih dari maksimal. Kepala Pimpinan dalam memberikan pembinaan kepada pegawai seperti memberikan pendidikan untuk menambah wawasan. Fasilitas yang diberikan LPD kepada pegawai seperti memberikan computer, kredit sepeda motor.
\end{abstract}

Kata Kunci : Peranan, Lembaga Perkreditan Desa, Pelayanan pada Masyarakat 
Peran Lembaga Perkreditan Desa (LPD) dalam Memberikan Pelayanan.......(Made Eka Agustini)

\begin{abstract}
In addition to having administrative and village villages, Bali Island also has villages that have genuine autonomy as the Customary Village or Pakraman Village. The Bali Provincial Government in this case has one of the village-level financial institutions, namely the LPD. The establishment and development of LPDs in Bali was basically to assist the development of each Customary Village as a force to safeguard its customs. The important role of the LPD is strongly felt by the community, especially to support activities such as rituals and Hindu holidays. This research was conducted with the aim to find out how the existence of rural credit institutions in providing servic123es to Desa Adat Legian. The research method used in this study is qualitative descriptive. Data collection techniques used are observation, documentation, interviews. Data analysis techniques used are data presentation, data analysis, conclusions. The Chief Executive during his term has carried out a good service process. In addition, the Head of the LPD Leadership in carrying out their duties has rules based on the SOP. The types of services available at the Legian LPD have been implemented more than maximally. The Head of Leadership in providing guidance to employees such as providing education to add insight. Facilities provided by LPD to employees such as providing computers, motorcycle loans.
\end{abstract}

Keywords : The Role, Village Credit Institutuions, Service to The Community

\title{
PENDAHULUAN
}

Pulau Bali selain memiliki kelurahan dan desa yang bersifat administratif, juga memiliki desa yang mempunyai sifat otonomi asli dengan sebutan Desa adat/ Desa Pakraman. Ciri khas desa adat adalah adanya unsur Tri Hita Karana yaitu Parahyangan, Palemahan, dan Pawongan. Ketiga unsur ini dikaitkan dengan peraturan Desa Adat itu sendiri yang disebut dengan awigawig. Kebijakan pembangunan pedesaan dapat dipilah menjadi tiga kelompok. Pertama, kebijakan yang secara tidak langsung yang mengarah pada sasaran tetapi memberikan suasana yang mendukung tercapainya kegiatan sosial ekonomi masyarakat desa seperti penyediaan sarana dan prasarana, penyempurnaan peraturan perundang-undangan yang menunjang kegiatan sosial ekonomi masyarakat. Kedua, kebijakan yang secara langsung mengarah pada kegiatan sosial ekonomi seperti sandang, pangan, perumahan, pendidikan, dan kesehatan. Ketiga, kebijakan khusus yang menyangkut masyarakat melalui upaya dengan melakukan kegiatan ekonomi sesuai dengan budaya setempat.

Pelayanan publik merupakan pelayanan yang diberikan oleh pemerintah kepada masyarakat atas dasar kepentingan umum. Pelayanan publik dapat diartikan sebagai pemberi 
layanan kepada individu atau sekelompok orang yang mempunyai kepentingan pada suatu instansi sesuai dengan aturan dan tata cara yang telah ditetapkan. Pemberi pelayanan adalah tugas dari pemerintah yang diberikan kepada masyarakat, yang artinya pemerintah dalam hal ini bukan hanya melayani dirinya sendiri atau dilayani oleh rakyat tetapi pemerintah adalah "pelayan rakyat". Dengan demikian untuk mengatur pelaksanaan pelayanan tersebut pemerintah mengeluarkan Undang-undang Nomor 25 Tahun 2009 tentang pelayanan publik yang memuat tentang kegiatan atau rangkaian kegiatan dalam rangka memenuhi kebutuhan pelayanan sesuai dengan peraturan perundang-undangan.

Pemerintah Provinsi Bali dalam hal ini memiliki salah satu lembaga keuangan milik desa yaitu adalah LPD. Berdiri dan berkembangnya Lembaga Perkreditan Desa (LPD) di Bali pada dasarnya untuk membantu pembangunan di tiap-tiap desa adat atau desa pekraman sebagai kekuatan untuk menjaga adat dan budaya Bali yang merupakan suatu strategis baru dalam meningkatkan sumber pendanaan terhadap anggota masyarakat. Berdiri sejak tahun 1984 dengan Peraturan Daerah (Perda) Nomor 2 Tahun 1988 tentang Lembaga Perkreditan Desa sebagai landasan yuridis yang pertama. Landasan hukum dari LPD di Provinsi Bali ini ditetapkan dengan keputusan Gubernur Bali Nomor 972 tahun 1984 tanggal 1 November 1984 yang selanjutnya ditetapkan menjadi Peraturan Daerah (Perda) Provinsi Bali No. 8 Tahun 2002 tentang Lembaga Perkreditan Desa tanggal 12 September 2002, serta diundangkan pada tanggal 16 September 2002 pada lembaran negara. Dengan berdirinya Lembaga Perkreditan sangat penting untuk membangun sumber daya yang berkaitan dengan budaya, sosial, dan ekonomi. Dengan demikian LPD telah menjadi usaha yang bergerak dalam bidang keuangan dan telah menjadi aset Desa Adat atau Desa Pakraman. Peran penting LPD sangat dirasakan oleh masyarakat di Bali terutama untuk mendukung kegiatan seperti odalan, hari raya besar umat hindu, dan dapat membantu masyarakat yang kurang mampu dibidang pendidikan serta memberikan bantuan pinjaman yang sifatnya mendadak apabila warga dianggap memiliki permasalahan dibidang modal usaha dan dapat membantu masyarkat yang memiliki keperluan keuangan yang bersifat mendadak seperti sakit dan upacara kematian.

Sedangkan dari segi pelayanan yang dilakukan oleh LPD kepada masyarakat yaitu sesuai dengan kebutuhan nasabah seperti prosedur yang sederhana, proses yang singkat, pendekatan personal serta kedekatan lokasi dengan nasabah untuk menjadi faktor keberhasilan LPD dalam 
Peran Lembaga Perkreditan Desa (LPD) dalam Memberikan Pelayanan.......(Made Eka Agustini)

menumbuhkan kepercayaan kepada masyarakat desa, sehingga masyarakat mempunyai rasa aman dalam menyimpan dan meminjam uang pada Lembaga Perkreditan Desa (LPD).

\section{Rumusan Masalah}

Berdasarkan uraian latar belakang diatas maka rumusan dalam penelitian ini adalah bagaimanakah Ekistensi Lembaga Perkreditan Desa dalam memberikan pelayanan pada masyarakat desa adat legian?

\section{Tujuan Penelitian}

Mencermati rumusan masalah diatas maka yang menjadi tujuan penelitian adalah untuk mengetahui bagaimanakah eksistensi kepemimpinan lembaga perkreditan desa dalam memberikan pelayanan pada masyrakat desa adat legian.

\section{KAJIAN TEORI}

\section{Pengertian Eksistensi}

Menurut Kamus Besar Bahasa Indonesia pengertian eksistensi adalah keberadaan, kehadiran yang mengandung unsur bertahan. Sedangkan Abidin (dalam Jurnal Maritfa Nika dan Mohammad Mukti 2013) mengatakan bahwa eksistensi adalah suatu proses yang dinamis, suatu yang "menjadi" atau "mengada". Jadi dapat diartikan eksistensi tidak bersifat kaku dan terhenti, melainkan lentur atau kenyal dan mengalami perkembangan atau sebaliknya kemunduran, tergantung pada kemampuan yang mengaktualisasikan potensi-potensinya.

Eksistensi juga bisa dikenal dengan satu kata yaitu "keberadaan”. Konsep eksistensi Dagun mengatakan (dalam Kartika, 2012: 15) bahwa kehidupan sosial manusia yang terpenting adalah keadaan dirinya sendiri atau eksistensi dirinya sendiri. Eksistensi juga dapat diartikan sebagai sesuatu yang menganggap keberadan manusia tidaklah statis, yang artinya manusia senantiasa bergerak dari kemungkinan ke kenyataan. Proses ini berubah bila menjadi sesuatu yang mungkin maka besok akan berubah menjadi kenyataan karena manusia mempunyai kebebasan untuk bergerak. Bereksistensi juga berarti berani mengambil keputusan yang dapat menentukan hidupnya. Konsekuensi jika kita bisa mengambil keputusan dan tidak berani berbuat maka kita juga tidak bisa bereksistensi dalam arti yang sebenarnya. 


\section{Konsep Pelayanan Publik}

\section{a. Pengertian Pelayanan}

Pelayanan adalah salah satu ujung tombak dari upaya untuk pemuasan pelanggan dan sudah merupakan keharusan yang wajib dioptimalkan baik oleh individu maupu organisasi, karena dari bentuk pelayanan yang diberikan dapat tercermin kualitas individu atau organisasi yang memberikan pelayanan.

Hardiyansah (2011: 11) mengatakan bahwa "pelayanan dapat diartikan sebagai aktivitas yang diberikan untuk membantu, menyiapkan, dan mengurus baik itu barang atau jasa dari satu pihak satu ke pihak lain". Pelayanan pada hakikatnya adalah serangkaian kegiatan atau proses pelayanan yang berlangsung secara rutin dan berkesinambungan yang meliputi seluruh kehidupan organisasi dalam masyarakat. Proses yang dimaksudkan dapat dilakukan dengan saling memenuhi kebutuhan anatara penerima dan pemberi pelayanan.

Pengertian pelayanan menurut Kotler dalam Litjan Poltak Sinambela dkk (2011: 4) mendefinisikan bahwa "setiap kegiatan yang menguntungkan dalam suatu kumpulan atau kesatuan, dan menawarkan kepuasan meskipun hasilnya tidak terikat pada suatu produk secara fisik". Dari definisi diatas dapat disimpulkan bahwa pelayanan adalah aktivitas yang dapat dirasakan melalui hubungan antara penerima dan pemberi pelayanan yang menggunakan peralatan berupa organisasi atau lembaga perusahaan.

\section{b. Pengertian Pelayanan Publik}

Pelayanan publik tidak terlepas dari masalah kepentingan umum yang menjadi asal usul timbulnya istilah pelayanan publik. Agus Dwiyanto (2008: 136) mengatakan bahwa pelayanan publik adalah serangkaian aktivitas yang dilakukan oleh birokrasi publik untuk memenuhi kebutuhan warga pengguna. Pengguna yang dimaksudkan disini adalah warga negara yang membutuhkan pelayanan publik seperti pembuatan Kartu Tanda Penduduk (KTP), Akta Kelahiran, Akta Nikah, Akta Kematian, dan lain sebagainya.

Litjan Poltak dkk (2011: 5) mendefinisikan bahwa pelayanan publik diartikan sebagai pemberi pelayanan sesuai dengan keperluan orang atau masyarakat yang mempunyai 
Peran Lembaga Perkreditan Desa (LPD) dalam Memberikan Pelayanan.......(Made Eka Agustini)

kepentingan pada organisasi. H.A.S Moenir (2008: 7) mengatakan "pelayanan umum adalah suatu usaha yang dilakukan oleh sekelompok orang atau birokrasi untuk memberikan bantuan kepada masyarakat dalam rangka mencapai tujuan tertentu”.

Pendapat lain dari Ratminto \& Atik Septi Winarsih (2010: 4) mengatakan bahwa pelayanan publik atau pelayanan umum dapat diartikan sebagai segala bentuk jasa pelayanan baik dalam bentuk barang publik maupun jasa publik yang pada prinsipnya menjadi tanggungjawab dan dilaksanakan oleh Instansi Pemerintah dalam rangka untuk memenuhi kebutuhan masyarakat maupun dalam rangka pelaksanaan ketentuan peraturan perundangundangan.

\section{c. Kualitas Pelayanan Publik}

Hardiyansyah (2011:36), mendefinisikan Kualitas pelayanan adalah sesuatu yang berhubungan dengan terpenuhinya harapan/kebutuhan pelanggan, dimana pelayanan dikatakan berkualitas apabila dapat menyediakan produk dan jasa yang sesuai dengan kebutuhan dan harapan pelanggan. Dalam hal ini, kualitas pada dasarnya berkaitan dengan pelayanan yang baik, yaitu sikap atau cara karyawan dalam melayani pelanggan atau masyarakat secara memuaskan.

Sedangkan menurut Wyckof dalam Tjiptono (2014;268) mengatakan bahwa kualitas jasa merupakan tingkat keunggulan yang diharapkan untuk memenuhi keinginan pelanggan. Terdapat dua faktor utama yang dapat mempengaruhi kualitas jasa yaitu jasa yang diharapkan dan jasa yang dipersepsikan. Leveince dalam Ratminto (2010: 175) mengatakan kualitas pelayanan dapat dilihat dari indikator-indikator sebagai berikut :

\section{- Responsivilitas}

Ini dapat mengukur daya tangkap provider terhadap harapan, keinginan, dan aspirasi, serta tuntutan dari customers.

- Responsibility

Suatu ukuran yang dapat menunjukkan seberapa jauh proses pemberian pelayanan publik itu dapat dilakukan dengan tidak melanggar ketentuanketentuan yang telah ditetapkan. 
- Akuntabilitas

Suatu ukuran yang menunjukkan seberapa besar tingkat kesesuaian antara penyelenggara pelayanan dengan ukuran-ukuran eksternal yang ada dimasyarakat dan dimiliki oleh steakholder, seperti nilai dan norma yang berkembang dalam masyarakat.

Jadi dari beberapa konsep diatas dapat didefinisikan bahwa kualitas adalah tingkat keunggulan yang diharapkan untuk memenuhi keinginan pelanggan untuk dapat memberikan persepsi positif dari pelanggan kepada perusahaan. Kualitas yang baik dapat berkontribusi besar terhadap kepuasan pelanggan sehingga nantinya akan menghasilkan loyalitas pelanggan yang baik.

\section{Lembaga Perkreditan Desa}

Lembaga Perkreditan Desa adalah lembaga ekonomi desa yang dipergunakan untuk penitipan dan penukaran uang di pedesaan. Sehingga pada dasarnya LPD berfungsi sebagai pengumpulan dana dan pemberian kredit. Peraturan Daerah Tingkat I Bali No. 2 tahun 1988 mengatakan bahwa "Lembaga Perkreditan Desa adalah suatu nama bagi usaha simpan pinjam milik masyarakat desa adat yang berada di Daerah Tingkat I Bali dan merupakan sarana perekonomian rakyat di pedesaan. Selanjutnya peranan LPD yang semakin berkembang dibidang usaha simpan pinjampun semakin luas sejalan dengan kemajuan teknologi informasi dan globalisasi perekonomian. LPD juga merupakan perusahaan yang dinamis sehingga mendorong pertumbuhan perekonomian, sehingga usaha LPD bukan saja sebagai penyimpanan dan pemberian kredit, tetapi juga sebagai alat lalu lintas pembayaran, stabilitas pembayaran dan stabilitas dinamisator pertumbuhan perekonomian suatu desa.

\section{METODE PENELITIAN}

Penelitian ini dilakukan di LPD Desa Adat Legian yang berlokasi di Jalan Raya Legian, Legian-Kuta, Kabupaten Badung. Di LPD Legian ini masyarakat menabung uang mereka dan melakukan pinjaman kredit. Jenis penelitian ini menggunakan metode penelitian deskriptif kualitatif. Informan dalam penelitian ini adalah Kepala Pimpinan LPD, karyawan LPD Desa 
Peran Lembaga Perkreditan Desa (LPD) dalam Memberikan Pelayanan.......(Made Eka Agustini)

Adat Legian, dan masyarakat Desa Adat Legian. Teknik pengumpulan data yang digunakan penelitian ini adalah observasi, dokumentasi, dan wawancara. Teknik analisis data dalam penelitian ini yaitu analisis data dari hasil penelitian dan pembahasan sesuai dengan pedoman wawancara dan kesimpulan berdasarkan hasil penelitian dan pembahasan.

\section{PEMBAHASAN}

Berdasarkan hasil wawancara bersama dengan Kepala Pimpinan LPD Desa Adat Legian selaku informan utama dalam penelitian ini, I Wayan Budiasa mengatakan bahwa : "saya menjadi Kepala Pimpinan di LPD Desa Adat legian ini sudah 19 tahun, selama saya menjadi Kepala Pimpinan untuk proses pelayanan kepada masyarakat saya rasa sudah dilakukan dengan baik, selain itu saya juga pernah melaksanakan survei secara keseluruhan dan bekerja sama kepada Universitas Mahasaraswati dengan hasil yang sangat memuaskan.

Hasil wawancara tentang aturan lpd dalam memberikan pelayanan, Kepala Pimpinan menjelaskan bahwa "dalam melakukan pelayanan kepada masyarakat LPD memiliki aturan yang diatur oleh Perda kemudian LPD diatur dengan ketentuan-ketentuan Pergub, dan LPD sendiri memiliki aturan yang dirilis dalam bentuk SOP, keseluruhan proses pelayanan yang dilakukan di LPD ada SOP nya dan ada job desk nya. Kalau untuk jenis pelayanan yang ada di LPD Desa Adat Legian ini menurut saya sudah diterapkan lebih dari maksimal, karena kita mempunyai perdub layanan yang bersifat transaksisonal yang terdiri dari program tabungan yang mempunyai banyak jenis yaitu tabungan sukarela, tabungan program, simpeda, tapura, simple, tabungan sehat dan kita juga memiliki tabungan baru yaitu tabungan tata.

Selain itu di perkreditan kita juga mempunyai kredit modal kerja, investasi, kemudian kita juga punya kredit konsumtif dan diantara itu diterjemahkan lagi dalam bentuk kredit pitra yadnya, kemudian ada kredit usaha pasar yang tanpa jaminan, kemudian ada kredit baru yang namanya lamensari dimana kita memberikan kemudahan kepada masyarakat untuk memanfaatkan fasilitas kredit LPD dalam memenuhi kebutuhan alat-alat yang digunakan untuk mendukung kehidupan sehari-hari misalnya seperti barang-barang eletronik dan juga ada kredit kendaraan. Untuk pelayanan sosial kita juga memberikan program beasiswa kepada anak-anak, kemudian sumbangan rutin kepada lansia, kemudian ikut mengembangkan budaya agama, yang 
artinya kita juga mendorong acara ngaben masal setiap 5 tahun jadi kita memberikan sumbangan dana kira-kira 400-500 juta dalam satu acara pitra yadnya tersebut dan kita selalu mendukung kegiatan-kegiatan yadnya yang ada di masyarakat berupa sumbangan dana bila mana ada masyarakat yang melaksanakan upacara yadnya yang sifatnya besar.

Cara pimpinan dalam memberikan pembinaan kepada pegawai LPD Desa Adat Legian menyatakan bahwa "kalau di lpd sendiri ada rencana kerja, rencana kerja itu diantaranya memberikan suatu pendidikan setiap tahun untuk menambah wawasan dan menambah kecerdasan karyawan jadi kita memang mempunyai program itu dan minimal 3 kali dalam setahun kita sendiri mesti melaksanakan pelatihan. Kemudian dari pelatihan itu terdiri dari pelatihan motivasi diri, kemudian pelatihan mengenai tugas-tugas yang diemban oleh karyawankaryawan kita misalnya pelatihan manajemen dana, pelatihan manajemen kredit, dan pelatihan marketing dan juga baru-baru ini kami sendiri secara swadaya bekerja sama dengan konsultan manajemen yang berkantor pusat di Kedonganan. Dalam hal ini kami melaksanakan pelatihan manajemen dana yaitu alko dan alba dan setelah itu kita melakukan pelatihan kredit, disamping melakukan pelatihan swadaya dilingkungan kami ada kordinator khusus untuk kordinator LPD Kecamatan Kuta sering melakukan pelatihan-pelatihan seperti itu".

Kepala Pimpinan LPD Desa Adat Legian dalam memberikan fasilitas menyatakan bahwa "di lpd ini kita mengutamakan untuk menyediakan fasilitas yang mereka butuhkan secara all out artinya sangat direncanakan misalnya ruangannya harus bagus, nyaman dan setiap orang mendapatkan satu computer. Fasilitas lainnya yaitu kita memiliki 2 mobil untuk melakukan pelayanan nasabah yang agak jauh, kemudian kita juga mempunyai fasilitas untuk pekerja diluar berupa tab, kemudian fasilitas lain yang kami sediakan adalah kolektor dan seluruh karyawan lpd kita berikan fasilitas kredit sepeda motor dengan bunga khusus demi menunjang pekerjaannya biar nyaman, kalau fasilitas yang bersifat dari segi keuangan selain gaji mereka dapat insentif untuk penampilan agar berkelas dan setiap tahun kita memberikan pakaian 3 setel sampai dengan sepatu dan bolpoint".

Informan lain dalam penelitian ini adalah karyawan LPD Desa Adat Legian yang di wawancarai pada bulan Desember, Ni Wayan Sariani mengatakan bahwa "saya menjadi karyawan LPD sudah 20 tahun. Selama saya menjadi karyawan di LPD Legian ini fasilitas yang saya dapatkan yaitu computer, dan untuk jenis pelayanan spesifik yang saya berikan kepada 
masyarakat yaitu seperti tabungan dan deposito. Kalau dalam proses pelayanan yang sedang berlangsung tersebut untuk pembukaan tabungan ada SOP nya dan untuk pembukaan rekening tabungan ada identitas diri yang harus dilengkapi terlebih dahulu. Untuk kendala-kendala saat proses pelayanan berlangsung saya rasa tidak ada kendala dan untuk bimbingan yang diberikan oleh Kepala pimpinan itu seperti membuat rencana kerja untuk tahun kedepannya. Kalau untuk menciptakan sistem pelayanan yang lebih maksimal saya rasa dengan cara membuatkan rekening seperti yang ada di LPD yaitu nasabah perutas yang biasanya kita melayani seperti saat upacara kita memberikan parsel atau pemuliaan nasabah dan untuk pelayanan yang saya berikan kepada masyarakat sudah sesuai dengan kebutuhan masyarakat.

Informan lain dari penelitian ini adalah masyarakat Desa Adat Legian yang diwawancarai pada bulan desember, Ni Wayan Rini ( 37 tahun ) mengatakan bahwa "pelayanan yang diberikan oleh LPD menurut saya sudah lebih dari maksimal. Menurut saya keberadaan LPD Legian ini dapat memberikan manfaat yang sangat baik karena dengan adanya LPD Legian ini dapat membantu perekonomian masyarakat Legian sendiri. Pelayanan yang biasa saya lakukan di LPD Legian ini seperti tabungan dan kredit. Kalau untuk aturan dalam meminjam kredit biasanya saya hanya memberikan ktp dan terdaftar sebagai anggota banjar/ Desa Adar Legian. Kalau untuk alur pelayanan yang ada di LPD Legian menurut saya sudah dapat diakses dengan cepat dan dalam segi pelayanan LPD Legian juga sudah memberikan pelayanan yang baik dan dapat memberikakan kenyamanan kepada nasabah.

Berdasarkan hasil wawancara dalam penelitian ini dapat menunjukkan Kepala Pimpinan LPD Desa Adat Legian dalam melakukan proses pelayanan kepada masyarakat sudah dilaksanakan dengan baik dan kepala pimpinan juga pernah melakukan evaluasi dengan hasil yang memuaskan. Dalam jenis pelayanan yang ada di LPD Legian juga sudah diterapkan secara maksimal. Kepala pimpinan LPD Legian dalam memberikan pembinaan kepada pegawai biasanya dengan cara memberikan suatu pendidikan setiap tahun untuk menambah wawasan dan kecerdasan karyawan. Dalam penyediaan fasiitas LPD Legian memberikan fasilitas kepada karyawan seperti ruangan yang nyaman, computer, kredit sepeda motor dengan bunga yang relatif rendah. Kepala Pimpinan LPD juga menjelaskan bahwa aturan yang ada di LPD sudah sesuai SOP dan Job desk masing-masing tetapi LPD Legian juga memiliki aturan seperti mulai 
bekerja dari pukul 8 pagi sampai dengan pukul 4 sore kecuali hari sabtu dimana jam kerja dilaksanakan mulai pukul 8 pagi samapi dengan pukul 1 siang.

\section{KESIMPULAN}

Berdasarkan hasil penelitian dan pembahasan yang telah diuraikan penulis pada bab sebelumnya, maka dapat disimpulkan bahwa Kepala Pimpinan LPD Desa Adat Legian selama menjabat sudah melakukan proses pelayanan dengan baik kepada masyarakat selain itu Kepala Pimpinan LPD juga pernah melaksanakan survei secara keseluruhan dengan hasil yang memuaskan. Selain itu untuk jenis pelayanan yang ada di LPD Legian juga sudah diterapkan secara maksimal karena LPD Legian mempunyai perdub layanan yang bersifat transaksional. Dalam hal aturan LPD Legian sendiri mempunyai aturan berdasarkan SOP dan Job Desk nya masing-masing. Selain itu Kepala Pimpinan LPD Legian juga memberikan pembinaan seperti memberikan pendidikan setiap tahun untuk menambah wawasan pegawai. Selain itu LPD juga bisa meningkatkan dan mendorong pertumbuhan perekonomian dan pembangunan di Desa Adat serta sebagai sumber pendapatan Desa Adat. Kehadiran LPD juga bisa turut memacu pelaksanaan pembangunan Desa Adat. Dalam segi fasilitas, LPD memberikan fasilitas satu unit computer dan fasilitas berupa kredit sepeda motor ke pegawai dengan bunga yang khusus demi menunjang kenyamanan pegawai.

\section{DAFTAR PUSTAKA}

Atmadja, Anantawikrama Tungga. 2011. "Penyertaan Modal Sosial dalam Struktur Pengendalian Intern Lembaga Perkreditan Desa (LPD): Studi Kasus pada LPD Desa Pakraman Penglatan, Kecamatan Buleleng, Kabupaten Buleleng, Propinsi Bali”. Diakses tanggal 31 Januari 2017.

Boediono, \& Wayan Koster. 2008. Teori dan Aplikasi Statistika dan Probabilitas. Bandung: PT Rosdakarya. 
Peran Lembaga Perkreditan Desa (LPD) dalam Memberikan Pelayanan.......(Made Eka Agustini)

Depdagri-LAN., 2008. Modul Kebijakan Pelayanan Publik, Diklat Teknis Pelayanan Publik, Akuntabilitas dan Pengelolaan Mutu (Public Service Delivery, Accountability, and Quality Management). Jakarta: LAN.

Dwiyanto, Agus. 2008. Mewujudkan Good Governance melalui Pelayanan Publik. Yogyakarta : Gadjah Mada University Press.

Hardiansyah. 2011. Kualitas Pelayanan Publik Konsep, DImensi, Indikator, dan Implementasinya. Yogyakarta: Gava Media.

Kusdarini, Eny. 2011. Dasar-Dasar Hukum Administrasi Negara dan Asas-Asas Umum Pemerintahan yang Baik. Yogyakarta: UNY Press.

Mahmudi, M., 2005. Manajemen Kinerja Sektor Publik. Akademi Manajemen Perusahaan YKPN. Yogyakarta.

Moenir. H.A.S. 2008. Manajemen Pelayanan Umum di Indonesia. Jakarta: Bumi Aksara.

Moleong, Lexy J. 2013. Metode Penelitian Kualitatif. Edisi Revisi. Bandung : PT. Remaja Rosdakarya.

Mutia, Sahibah. 2013. "Eksistensi Kehidupan Sosial” Diunduh pada tanggal 30 Maret 2014. http://www.fsrd.itb.ac.id/wp-content/uploads/EKSISTENSI.pdf.

Poltak Sinambela, Litjan dkk. 2011. Reformasi Pelayanan Publik Teori, Kebijakan, Implementasi. Jakarta: Bumi Aksara.

Ratmino dan Atik Septi Winarsih. 2008. Manajemen Pelayanan. Yogyakarta: Pustaka Pelajar.

Rintuh, Cornelius dan Miar. 2009. Kelembagaan dan Ekonomi Rakyat. Yogyakarta : BPFE Yogyakarta.

Saefullah, H.A.D., 2008. Pemikiran Kontemporer Administrasi Publik Perspektif Manajemen Sumber Daya Manusia dalam Era Desentralisasi. Bandung: AIPI dan PK2W Lemlit Unpad.

Saryono \& Mekar Dwi Anggraeni. 2011. Metodolgi Penelitian Kualitatif Dalam Bidang Kesehatan Edisi Kedua. Yogyakarta: Penerbit Nuha Medika. 
Sugiyono, 2011. Metode Penelitian Kuantitatif Kualitatif dan R\&D. Bandung: Alfabeta..

Sutopo. 2006. Metodologi Penelitian Kualitatif. Surakarta: UNS.

Tjiptono, Fandy. 2008. Strategi Pemasaran. Edisi 3. Yogyakarta : C.V Andi offset.

Tjiptono, Fandy. 2014. Pemasaran Jasa. Yogyakarta: C.V Andi offset.

Umi Narimawati. 2008. Metodologi Penelitian Kualitatif dan Kuantitatif, Teori dan Aplikasi. Bandung: Agung Media. 